\title{
ENSINO DA RESPONSABILIDADE CIVIL NA GRADUAÇÃO EM DIREITO
}

\author{
TEACHING TORT LAW AT COLLEGE GRADUATION
}

\author{
Giselda Maria Fernandes Novaes Hironaka* \\ Fernando Dias Andrade
}

\begin{abstract}
Resumo:
Diante da importância do tema, este ensaio discute o que significa hoje o ensino da responsabilidade civil na graduação (tal matéria é estudada mais no interesse de formar profissionais ativos na chamada indústria da indenização do que agentes eticamente comprometidos com práticas de prevenção de danos ou de proteção de direitos, o que mostra que, nesse interior do estudo da responsabilidade civil, pouca atenção é dispensada ao conceito de bem jurídico); por que a responsabilidade civil faz parte do Direito Civil (embora pareça matéria acessória à matéria do Direito das obrigações, a responsabilidade civil está na origem do próprio Direito Civil: este é fundamentado justamente na necessidade de se reparar danos ou, melhor ainda, preveni-los - sem o qual não há segurança na sociedade); por que a responsabilidade civil é uma parte singular do Direito Civil (a responsabilidade civil pressupõe uma estrutura que contenha todos os instrumentos argumentativos necessários à elaboração de manuais próprios, dos princípios gerais às conclusões para cada caso concreto visível ou previsível, mas, principalmente, é o caso de avançar dos manuais técnicos aos tratados de caráter crítico, uma vez que o exigem a importância da matéria e a relação com os outros campos do Direito); por que ela é uma parte tão importante quanto as demais (somente um estudo que enfatize a singularidade do direito dos danos pode, em lugar de prontamente lançar o graduando em Direito no ânimo do cálculo indenizatório, proporcionar a reflexão em torno dos fundamentos e dos elementos da responsabilidade, o que envolve, inclusive, a reflexão a respeito da relação da responsabilidade civil com outras áreas do Direito e, o que é mais rico, um contato direto com o mundo da prática visível em outras ciências e humanidades); se ela pode se tornar uma parte mais importante do que as demais (ela pode ser a parte singular superior por excelência no sistema pedagógico do Direito Civil, desde que cumpra aquela tarefa intelectual de desenvolver de forma consistente a sua teoria geral; cumpre mostrar que a responsabilidade civil pode ser uma forma de ver o Direito Civil como um instrumento de fortalecimento entre os cidadãos, e para tanto será necessário abandonar a perspectiva da indústria da indenização); por que tudo isso é relevante para o ensino do Direito Civil na graduação (trata-se de desenvolver uma discussão fundada exclusivamente em um ideal de excelência universitária cujo paradigma é a universidade pública, sem nenhuma abertura para os padrões anti-universitários da universidade privada ou dos cursinhos preparatórios; trata-se de explicitar que o ensino da responsabilidade civil deve expressar um ideal de universidade que tem sido muito atacado pelos arsenais da perspectiva indenizatória, cuja principal morada são a universidade privada e os
\end{abstract}

\footnotetext{
Doutora e Livre-Docente em Direito pela Universidade de São Paulo. Professora-Associada do Departamento de Direito Civil da Faculdade de Direito da Universidade de São Paulo. Membro fundador e ex-secretária geral da Associação Brasileira do Ensino do Direito - ABEDi. Ex-Procuradora Federal.

** Doutor em Filosofia pela FFLCH/USP, doutorando em Direito pela Faculdade de Direito da Universidade de São Paulo. Professor Adjunto de História da Filosofia na UNIFESP.
} 
cursinhos preparatórios); o que significará, considerados esses aspectos, o ensino da responsabilidade civil na graduação (o estudo da responsabilidade civilé oportunidade única para estabelecer uma rica relação inter-seccional entre as diversas partes do Direito Civil e interdisciplinar entre o Direito Civil e as demais áreas jurídicas - é um instrumento de ingresso do pensamento jurídico no conjunto dos problemas das ciências humanas, com as quais ele pode tanto dialogar quanto confrontar); e, enfim, quais os resultados para o ensino do Direito como um todo (provavelmente não chegaremos a um novo modelo único de estudo da responsabilidade civil e do Direito, mas, sim, a muitos outros novos modelos que correspondam às visões pedagógicas localizadas e particularizadas que se puderem manifestar no interior deste nosso grandioso País).

Palavras-chaves: Ensino da responsabilidade civil. Divisões do Direito Civil. Teoria do ensino do Direito. Ensino do Direito e Ética. Universidade.

\begin{abstract}
:
Considering the importance of the subject, this essay discusses what the teaching of tort law in undergraduate means nowadays (this subject has been studied more in the interest in training active professionals for the so-called damages' industry than agents ethically bounded with damages prevention practices or rights protection, what evidences that, in this aspect of the study of tort law, a few attention is assigned to the concept of legal goods); as tort law is a part of private law (despite it seems a accessory subject of the law of obligations, tort law was in the origins of private law: this statement is based in the need of repairing damages or, more precisely, to prevent them - without which there is not security in society); as tort law is a part of private law (tort law presupposes a structure which contains all argumentative tools able for the elaboration of suitable handbooks, with general principles to conclusions for each case, predictable or not, but, mainly, whether an advance from handbooks to technical-critical treatises is needed, due to the importance of this subject and its relation with other fields of law); as tort law is an important part of private law (it is just a study which emphasizes the singularity of tort law can offer a reflection about the founding and elements of tort law instead of present to undergraduate law students in the study of compensation calculations, which comprehends the reflection about the relation with tort law and other law areas and the direct contact to the world of visible practice in other sciences and humanities); if tort law can be the most important part of private law (it can be the upper single part in the pedagogic system of private law, unless tort law accomplishes the intellectual task to develop with consistency its general theory; on must evidence that tort law may be a way to see private laws as a strengthening tool for people); as all of these statements are relevant for the teaching of private law in undergraduate (it is about to develop a discussion based on a ideal of graduation excellence which paradigm is the public university, with no overture for anti-university patterns or private universities and repetition courses; it is about to highlight that the teaching of tort law must evidence an ideal of university that has been challenged by the paradigm of compensation's perspective, argued by private universities and repetition courses); this will mean the teaching of tort law in undergraduate (the study of tort law is the unique opportunity to establish a rich intersectional relation among the parts of private law as well as the other law subjects - it is the way to start the study of the legal thought in the set of social sciences problems, with which tort law can be in accordance with or in opposition of it); finally, which results can be reached to the teaching of tort
\end{abstract}


law (probably we cannot reach a new unique model of study of tort law and even the law, but on might reach new other models that correspond to a localized and particularized pedagogic views that are going to bear in our great country).

Keywords: Teaching Tort Law. Civil Law sections. Learning of Law's Theory. Learning of Law and Ethic. University.

1. Palavras iniciais e colocação das indagações acerca do ensino da responsabilidade civil na graduação

Responsabilidade civil é, sem dúvida, uma das áreas mais desafiadoras do ensino do Direito Civil. Essa área - conhecida em outros países pelo nome provavelmente mais apropriado de Direito dos Danos - está, apesar de ter sido convencionada como uma seção à parte no currículo do Direito Civil e como um título à parte no Código Civil, muito aquém de ser uma parte independente. Assim como a cidade de Paris é uma encruzilhada que liga a maior parte das demais capitais da Europa, a responsabilidade civil é uma encruzilhada entre os princípios do Direito ("não causar dano a ninguém”, "dar a cada um o que é seu") e o que mais no sistema do Direito Civil, é uma encruzilhada entre o Direito Civil e o Direito Penal (que pensará a responsabilidade penal a partir do conceito de responsabilidade civil) e, ainda, uma encruzilhada - para além de uma extensão - entre o direito das obrigações (a base tradicional da parte especial do nosso Código Civil) e o restante das áreas da parte especial do Direito Civil. Finalmente, a responsabilidade civil representa, entre os propósitos do direito, a finalidade mais pura e tradicionalmente civilista (porque a finalidade mais protetora do patrimônio), ainda que não necessariamente a mais importante (porque o novo Direito Civil pode ser, e é, um direito que excede as preocupações patrimoniais).

Importa, assim, pensar as razões e finalidades do Direito Civil quando se discute um tema tão prático e concreto quanto é o tema do ensino da responsabilidade civil em um dos espaços que lhe estão abertos - a graduação. Pensar a responsabilidade civil na graduação pode significar pensar o que entendemos ser a finalidade do ensino do próprio Direito Civil em todas as áreas, pois diante desse tema não se pode ficar indiferente. É preciso atribuir-lhe um valor específico no sistema do Direito Civil, e esse valor será um indicativo do que pensamos ser importante dentro do próprio Direito Civil, bem como de qual o tipo de estudante queremos ver graduado em Direito.

Pode parecer estranho, em uma visão tradicional, enfatizar o estudo da responsabilidade civil, atribuindo-lhe essa importância de fator relacional entre distintas áreas do Direito Civil ou mesmo do próprio Direito. De fato, se pensarmos a maneira como em geral ou tradicionalmente as matérias do Direito Civil eram distribuídas para o ensino primeiro na graduação em cinco anos de estudos de Direito Civil (parte geral, direito das 
obrigações, direitos reais, direito de família, direito das sucessões), ainda estranharemos a patente amputação de partes certamente importantes - em especial a teoria dos contratos (tanto parte geral quanto os contratos em espécie), mas também a responsabilidade civil, que a despeito de sua presença em determinado momento da parte geral (aquele em que se apresenta a idéia de ato ilícito) e de um espaço próprio adiante no Código Civil era ignorada ou relegada a alguns capítulos complementares nos manuais tradicionais de instituições do Direito Civil.

Obviamente, havia em Direito estrangeiro, e em seguida em Direito brasileiro, considerável doutrina da qual resultaram tratados ou estudos específicos sobre a responsabilidade civil (tradição que, entre nós, foi devidamente inaugurada pela obra de Alvino Lima, nos anos 30 do século XX). No entanto, essas obras sempre ficaram longe da graduação, no sentido de que nunca foram determinantes para que se incluísse, no quadro geral do currículo de Direito Civil, uma divisão específica para o ensino da responsabilidade civil nessa etapa da formação jurídica.

Só muito recentemente essa possibilidade tem sido pensada e introduzida em alguns programas de graduação no Brasil. Como se sabe, em algum momento deveria ser o caso de abrir espaço ao direito dos danos, porque a sua própria estrutura legal e institucional pedia um estudo específico. Apontando para essa tendência, surgiram seções dedicadas à responsabilidade civil, e hoje já é comum encontrar nos manuais de Direito Civil para a graduação pequenas obras exclusivamente dedicadas a essa área. Esses estudos tornaram-se significativos e indispensáveis a qualquer manual que não os inclua com ênfase. Entretanto, há todos os motivos para conceder à responsabilidade civil espaço ainda maior dentro do conjunto geral dos temas de Direito Civil para a graduação, isto é, mais do que um volume tímido entre o conjunto de volumes que formam um extenso manual de Direito Civil, é preciso ampliar o tamanho do volume da responsabilidade civil, tanto porque ela tem repertório para isso quanto porque ela apresenta, justamente, um excelente campo de conexão com outras áreas do Direito e do Direito Civil. Já perceberam essa amplidão os tratados de responsabilidade civil que hoje são voltados para um público de profissionais e de pós-graduação, mas se considerarmos que o ensino do Direito Civil na graduação se beneficia cada vez mais do estudo de casos ao lado do estudo da estrutura lógica e teórica do Direito Civil, então talvez seja relevante transformar os tímidos volumes sobre responsabilidade civil (escritos para a graduação) em vigorosos volumes de exposição teórica e, principalmente, de elucidação de casos. Definitivamente, os casos práticos da responsabilidade civil são um meio eficiente de apresentar ao graduando em Direito as dificuldades e diferenças de interpretação envolvidas na solução desse viés aparentemente tão simples quanto o "não lesar a ninguém" e o "dar a cada um o que é seu". Viés apenas aparentemente simples. 
Assim, é o caso de se pensar: o que significa hoje o ensino da responsabilidade civil na graduação? Por que a responsabilidade civil faz parte do Direito Civil? Por que a responsabilidade civil é uma parte singular do Direito Civil. Por que ela é uma parte tão importante quanto as demais. Se ela pode se tornar uma parte mais importante do que as demais, por que tudo isso é relevante para o ensino do Direito Civil na graduação? O que significará, consideradas essas indagações, o ensino da responsabilidade civil na graduação? E, enfim, quais os resultados que podem ser alcançados para o ensino do Direito como um todo (por que a responsabilidade civil não se reduz ao Direito Civil e nem mesmo ao Direito)?

2 Qual o significado, hoje, do ensino da responsabilidade civil na graduação?

Já foi mencionado o fato de que a responsabilidade civil ganhou mais espaço dentro dos manuais de Direito Civil. Qual terá sido o motivo? Será que esse fato responde a um interesse crescente por parte do público leitor ou a um interesse pessoal e pedagógico dos autores e professores de Direito Civil? Talvez um misto de ambos, e no que diz respeito ao interesse do leitor referimo-nos diretamente ao interesse dos estudantes de graduação (principal público-alvo dos manuais de Direito Civil). É possível verificar um interesse crescente por parte desse público (ou dessa "clientela", como alguns gostam de dizer)? Talvez a resposta possa ser mesmo positiva, mas um interesse desenhado apenas desse modo não teria importância significativa, podendo até mesmo comparecer nefastamente.

Em outras palavras, a quase totalidade dos acadêmicos de Direito que pretendem advogar pensa na advocacia como um meio de ganhar dinheiro (o que faz sentido em termos práticos, afinal...) não formam uma espécie incomum os advogados que se dedicam às conseqüências da inexecução das obrigações e, em especial, à responsabilidade civil. De fato, qual a figura, hoje, daquele que advoga em favor da compensação ou reparação dos danos? Não por acaso, é uma figura às vezes malquista ou malvista, por ser rotulado como (ou por ser, de fato, em tantas vezes) um agente em constante busca da indenização máxima. Esse raciocínio prático, que automaticamente relaciona o dano à necessidade de reparação, e esta à necessidade de indenização, domina a compreensão corrente sobre as finalidades da responsabilidade civil.

Essa é também a compreensão que os acadêmicos de Direito costumam ouvir de seus próprios professores. Na graduação atual, o acadêmico quer dos professores a apresentação das fórmulas mágicas que permitirão identificar todas as situações em que seja possível constatar uma possibilidade viável de indenização. Em lugar de conhecer e proteger os direitos ou de prever e se precaver contra os danos, talvez importe mais para muitos acadêmicos (e para muitos professores, infelizmente) ignorar a prática da precaução e desenvolver exclusivamente as técnicas da chamada indústria da indenização. Por essa 
razão - e como não poderia deixar de ser - boa parte da bibliografia doutrinária atual tem se desenvolvido com vistas a alimentar ou responder a esse apelo por instrumentos que garantam êxito nas demandas indenizatórias. Em outras palavras, o crescente interesse pela responsabilidade civil pode estar sendo alimentado exclusivamente pelo interesse em ingressar na indústria da indenização, e não no interesse de formar uma sociedade mais segura e mais precavida.

Assim, como pode ser visto, hoje, o ensino da responsabilidade civil nos cursos de graduação? Seja por via ou-não dos manuais de Direito Civil (e sejam eles bons ou medianos), seja nas aulas regulares da graduação, seja nos cursos de extensão, seja nos cursinhos paralelos ao fim da graduação, a responsabilidade civil é este interessante lugar em que se aprende a calcular indenizações.

Não deixamos de reconhecer, é claro, que a indenização é uma parte importante do estudo da responsabilidade civil e da inexecução das obrigações, e certamente é uma das suas grandes finalidades práticas. No entanto, há dois aspectos significativos nesse assunto que se deve registrar: primeiro, justamente por ser a indenização uma finalidade, há antes dela etapas e temas que podem ser mais importantes e fundamentais; segundo, mesmo entre as finalidades da responsabilidade civil, talvez a indenização não seja a finalidade mais importante.

Antes de se estudaraindenização, há todauma base teórica da responsabilidade civil que precisa ser apresentada e conhecida. Essa base se confunde com as bases da teoria das obrigações, e pressupõe o pleno conhecimento do que é uma obrigação, convencionada ou-não. A responsabilidade civil obedece a uma lógica semelhante à da inexecução das obrigações: assim como é preciso reparar um dano causado pelo descumprimento de uma obrigação, deve-se reparar o dano causado independentemente de relação contratual. Isso é correto. Contudo, é preciso pensar no significado profundo de obrigação e de bem jurídico se pretendemos sustentar a sua proteção e se, depois, quisermos igualmente sustentar a reparação dos danos que decorram do desrespeito à obrigação pactuada, ou do bem jurídico lesado. Nos cursos de graduação de hoje, há muito interesse em se discutir a indenização, mas pouco debate a respeito do que é obrigação e bem jurídico - e essa é uma lacuna terrível, a qual se deve buscar solucionar urgentemente.

Por que seria esta uma lacuna tão grave? Pensemos a partir da própria idéia de indenização. Qual a racionalidade de se defender a reparação de um dano se não pudermos definir o valor de um bem ou de uma obrigação (premissa necessária para perceber se houve dano, uma vez que este é um prejuízo sobre o valor da coisa)? Somos tão acostumados a lidar com a idéia de indenização (hábito que inclui também a idéia de multa ou de cláusula penal) que talvez cheguemos a identificar o valor da indenização com o valor da própria coisa, ou como o principal valor da coisa. Ou seja, quando vemos a indenização como a grande finalidade ou razão de ser da responsabilidade civil, ou da 
teoria das obrigações, perdemos de vista o valor do próprio bem jurídico e o substituímos pelo valor de um bem abstrato que o substitui. Será que isso é justo? Tenho certeza que não.

A concentração da nossa atenção no cálculo da indenização - no interesse pelo bem indenizatório em lugar do bem original - pode nos fazer perder a noção de bem e, conseqüentemente, as noções de direito (subjetivo) e de valor. Dessa forma, pode nos distanciar da compreensão do que é a dignidade de algo. No entanto, mesmo em uma perspectiva puramente prática - saber o valor original do bem para constatar o prejuízo e calcular a indenização -, o conhecimento do valor original do bem, da coisa, do direito ou da pessoa tem um lugar central. Dada essa constatação, por que perdê-lo de vista?

Se observarmos a estrutura costumeira dos manuais de Direito Civil na parte em que se dedicam à responsabilidade civil, veremos que sempre há no início do livro uma abordagem do que é o dano ou o ilícito. É nessa análise, geralmente, que se concentra tudo o que de essencial o autor tem a dizer sobre o bem jurídico. Este, inclusive, é tratado por razões indiretas, uma vez que o alvo principal do início da obra sempre é a definição do ilícito (como um ato que não se deve realizar, mas que, se realizado, talvez gere um direito a ressarcimento), e não a definição de bem jurídico (que é justamente o bem primordial que não se deve ofender).

Em outras palavras, as obras de responsabilidade civil começam do ato ilícito, a partir da descrição de uma sociedade que desrespeita o patrimônio alheio, tanto privado quanto público. O leitor é apresentado à figura do dano, prática tão comum na vida diária dos homens. O dano é definido como um prejuízo material ou de apreciação econômica que o bem sofreu por conta do ilícito. Seria este um bom momento para se explorar, detalhadamente, o bem, mas nenhum doutrinador aproveita essa oportunidade. Ao contrário, estabelecida a compreensão de que o dano é um prejuízo sobre o valor econômico da coisa, do bem ou do direito, passa-se à investigação do nexo de causalidade entre autor do ilícito e dano sofrido; e, havendo a verificação do nexo causal, passa-se ao cálculo da indenização, que, por sua vez, se mede pela extensão do dano. Um grande e infindável círculo vicioso!

Nessa passagem do dano à indenização, o leitor é levado a acostumar-se, ainda, com certa forma (completamente técnica) de raciocinar sobre as relações entre autor e dano, valor do bem diante do dano (valor anterior e valor posterior ao dano), capacidade do autor para responder pelo dano e capacidade de seu patrimônio para prover a indenização. Toda a estrutura está preparada para servir ao motor da indústria da indenização: nela cabe toda uma tipologia de modalidades de ilícito (e das respectivas responsabilidades), cuja tendência é se tornar eterna, ainda que mutável, e que se mostra como o grande arsenal de que se pode servir o operador jurídico a fim de identificar os ilícitos e calcular a viabilidade das ações indenizatórias. 
Pouca ou nenhuma palavra há sobre a necessidade de se construir uma sociedade segura - não por meio da certeza da indenização, mas por meio da viabilidade da precaução. Esta é a sociedade para a qual somos formados e formamos, infelizmente: uma sociedade beligerante (de reparação, de indenização), não uma sociedade pacífica (de preservação, de precaução).

3 Proposta acerca de uma estrutura mais aberta a conteúdos de maior reflexão e investigação ética em torno da própria questão da responsabilidade

No que diz respeito à estrutura aqui citada dos manuais de responsabilidade civil - aquela que parte da apresentação do ilícito para explicar as modalidades de dano, as espécies de responsabilidade, os requisitos do nexo causal, as situações excludentes ou agravantes da responsabilidade etc. - , nota-se que é uma conquista histórica da doutrina e convém ser mantida como estrutura. Contudo, é muito importante que seja uma estrutura aberta a conteúdos de maior reflexão e investigação ética em torno da própria questão da responsabilidade. Uma reflexão assim conduzida permitiria, entre outras coisas, pensar melhor acerca do que é bem jurídico, da natureza e origem das circunstâncias que o lesam, ao lado de todo o percurso que objetiva explicar o que é o ilícito, por que o ilícito não deve ficar impune e quais os meios disponíveis para corrigir o dano pela indenização. $\mathrm{O}$ operador jurídico que se volta para a responsabilidade civil tem motivos para se ver como um grande arauto da justiça entre os homens, mas só o será verdadeiramente se estiver atento para todo esse trajeto, que vai muito além das fronteiras da questão simplesmente indenizatória.

Pode parecer estranho falar de uma reflexão sobre responsabilidade civil que não envolva, como finalidade principal ou única, o cálculo da indenização. É estranho justamente porque somos esta sociedade formada por princípios de justiça adversos à noção de preservação, mas esse estranhamento também é importante, pois evidencia o quanto já se pode estar viciado pelo hábito de identificar a indenização ao dano.

Em termos de orientação para o cálculo indenizatório, no entanto, as obras em geral estão bem descritas, tanto que acelera como nunca a chamada "indústria da indenização". Mesmo as obras sérias de doutrina não deixam de ser sensíveis a esse filão impressionante formado em torno da indústria, de maneira que em nosso universo jurídico pode-se com facilidade sentir que, a princípio, há meios para pedir indenização sobre tudo. A noção de responsabilidade, assim, multiplica-se por inúmeras especificidades, casos particulares que jamais serão a última palavra concreta em torno daquela hipótese. $\mathrm{Na}$ doutrina, avolumam-se os manuais de responsabilidade - quando voltados mais para um público profissionalizado - que se tornam apenas manuais práticos de investigação indenizatória. O leitor acadêmico de graduação, munido daqueles volumes sobre a 
responsabilidade civil, imagina, diante dessa bibliografia especializada cada vez mais multifacetada e volumosa, voltada para os profissionais do Direito, que o estudo da responsabilidade avança apenas por meio do acúmulo quantitativo de casos concretos. Trata-se de uma imagem que descreve uma realidade de mercado (os volumes mais vendáveis sobre responsabilidade são aqueles que mais fornecem instrumentos para mais - ou novas - modalidades indenizatórias), mas em parte também é uma imagem que reflete uma intuição correta, a de que os casos concretos são potencialmente infinitos e que quanto mais se conhecer deles, melhor.

De fato, foi dito no início deste texto: o estudo da responsabilidade civil se beneficia grandiosamente do estudo dos casos concretos. Todavia, há duas maneiras de fazer tal estudo, que ousaremos aqui denominar, respectivamente, perspectiva indenizatória e perspectiva reflexiva.

\subsection{Perspectiva indenizatória}

Por perspectiva indenizatória deve-se entender o que praticamente é ensinado hoje, aos acadêmicos de Direito, como o grande modelo do estudo da responsabilidade civil: é preciso conhecer as modalidades de dano para se constatar as viabilidades de indenização. Para essa finalidade, voltam-se tanto os volumes sobre responsabilidade civil que integram os manuais de Direito Civil quanto os grandes tratados de responsabilidade civil. E ao lado dessa perspectiva é possível identificar outra, a qual chamamos de reflexiva, que é uma maneira de pensar a responsabilidade contra a tendência costumeira de cair na tentação do cálculo indenizatório, isto é, pensar a responsabilidade evitando chegar ou concluir pelo cálculo indenizatório, ainda que se constate que ele é devido.

\subsection{Perspectiva reflexiva}

A perspectiva reflexiva - que não costuma estar presente nos manuais de Direito Civil que versam sobre a responsabilidade civil - é um esforço de pensar o sentido da responsabilidade, e não de torná-la um pretexto para se chegar ao pedido da indenização.

Significa a concepção dessas duas perspectivas a concepção de duas tendências opostas de estudo da responsabilidade civil? Não se pode dizer opostas, mas parecem ser complementares entre si; só não foram ainda analisadas dessa maneira. Pensamos ser válido experimentar ambas as perspectivas em conjunto: a perspectiva indenizatória teria muito a ganhar com a perspectiva reflexiva. Em termos acadêmicos e intelectuais a proposta é mais do que válida. Contudo, ficam as perguntas: seria viável? Chegaria a algum lugar? Só experimentando-a para saber. 
Ora, se se trata de experimentar uma outra forma de estudo da responsabilidade civil, e se estamos a pensar o ensino da responsabilidade civil na graduação, caberia perguntar: será que poderíamos experimentá-la já no ambiente da graduação? De todos os ambientes - ou etapas, talvez - de estudo de qualquer tema do Direito Civil, a graduação parece ser na prática o menos experimental e também o ambiente mais apegado aos manuais. No entanto, por que, se é na graduação que, teoricamente, estão as mentes mais abertas à nova informação, aos novos temas - e, em conseqüência, às novas perspectivas? Porque é na graduação que os educadores mais têm medo de tentar novos procedimentos de investigação; é na graduação que os educadores mais se aferram às estruturas fixas dos manuais e dos tratados, reverenciando programas fixos que não se ousa modificar.

Pensamos que esse medo coletivo que nos assoma como educadores é também um erro coletivo; não é por amor à preservação de uma metodologia científica vitoriosa que nos mantemos fixos aos nossos programas imutáveis, e sim por falta de prática da nossa própria reflexão. É comum, entre nós, esse apego a currículos fixos, como se a antigüidade do currículo quisesse significar sua maior validade (quando pode ser exatamente o contrário em termos científicos). O que dizer do currículo padronizado em torno da responsabilidade civil? Ele é consagrado, sem dúvida, mas será que haveria razões para modificá-lo? Se houver, será que a graduação, enfim, é ambiente adequado para tentar fazê-lo?

Nem mesmo Paulo Freire tem uma posição enfaticamente favorável aos experimentalismos na graduação universitária - ele estava mais preocupado com a principal fase de qualquer educação, a educação fundamental -, mas é certo que há um consenso dos educadores que se dedicam ao ensino universitário quanto ao valor experimental único que a graduação possui. Em outras palavras: é na graduação que mais se pode criar quando se trata de ensino universitário. Entretanto, se por vícios ou maus costumes somos temerosos de fazê-lo, será útil fazer saber - a todos os envolvidos com o ensino universitário - que a experimentação na graduação é o laboratório mais privilegiado para a descoberta do que é possível fazer em termos de conhecimento científico ou acadêmico do Direito.

Na graduação em Direito - tempo e lugar em que se apresentam as bases, além dos grandes temas que deverão ser para sempre aprofundados - pode ser testada a viabilidade pedagógica e racional de qualquer perspectiva teórica a respeito do Direito. Inclusive, evidentemente, da responsabilidade civil. Se alguma inovação que se perceber necessária, em termos de didática ou de análise científica da responsabilidade civil, caberá ao docente testá-la no espaço aberto da graduação, uma vez que esta é um espaço que não apenas permite essa experimentação como ainda oferece instrumentos para corrigir os próprios erros interpretativos que ali se percebam. Como a graduação em Direito, em suma, não há espaço mais privilegiado para se pensar os alcances da responsabilidade civil e as necessidades de sua reformulação pedagógica. 
Nesse sentido, afirma-se que é na graduação que se deve tentar qualquer mudança na abordagem da responsabilidade civil. Quaisquer que sejam as conseqüências.

Essas mudanças serão aqui descritas, mas antes cabe alertar sobre a necessidade de manter o que deve ser mantido. Cabe chegar a uma outra - não exatamente "nova", mas, sim, "outra", não-industrial - compreensão da responsabilidade civil. Essa outra compreensão, todavia, não necessita ainda de qualquer propensão anárquica ou demolidora, ela pode perfeitamente manter o que deve ser mantido (ou-não será mais o próprio instituto da responsabilidade civil), mas precisa mudar o que deve ser mudado (ou-não haverá novidade). Assim, mutatis mutandis, o que é o ensino reflexivo da responsabilidade civil na graduação? Vamos analisar.

\section{Por que a responsabilidade civil faz parte do Direito Civil?}

Não é possível pensar o Direito Civil sem a responsabilidade civil. Não é possível, nem mesmo, pensar o próprio Direito sem a responsabilidade civil. Entre os princípios gerais do Direito já consagrados no mundo clássico dos romanos, inclui-se a regra máxima da responsabilidade civil, o princípio que ordena "não causar dano a ninguém". Será possível pensar algum ramo do Direito sem a presença dessa máxima? Por certo que não. Dessa maneira, mesmo que seja válida uma nova compreensão da responsabilidade civil, ela não pode deixar de partir desta base que é o princípio "não causar dano a ninguém".

Apenas esse princípio serviria para mostrar que não há sistema jurídico que prescinda da responsabilidade civil, ainda que por extensão. De fato, a responsabilidade civil é uma espécie de instrumento à mão de qualquer ramo do Direito, tanto que se pode falar, com correção, da responsabilidade aplicada a qualquer área do Direito: responsabilidade ambiental, responsabilidade penal, responsabilidade industrial, responsabilidade consumerista e assim por diante. Mas esses inúmeros ramos jurídicos se apresentam como extensão da responsabilidade civil, e não como alguns de seus paralelos. Nessa ordem de idéias, é possível com clareza e facilidade concluir que é no Direito Civil que se verifica a forma pura da responsabilidade, na medida em que se puder falar de uma forma pura. Assim, se possível for falar de responsabilidade em outros ramos do Direito que não o Direito Civil, no caso do Direito Civil puro a responsabilidade que ali aparece é a responsabilidade na sua forma fundamental, à qual as demais devem, por necessidade sistêmica e concreta, corresponder. A responsabilidade civil é parte do Direito Civil porque o Direito Civil pressupõe o respeito aos direitos e bens dos titulares de direitos. Quando não for mais necessário esse respeito, não será mais necessária a visão 
da responsabilidade civil e, em conseqüência, o primado do Direito Civil (como seu solo original) não precisará mais ser obedecido.

Isso não é tão evidente quanto parece. Do ponto de vista da indústria da indenização, por exemplo, é possível, sim, ver em todos os ramos do Direito um campo aberto para a responsabilização (civil ou-não), mas o preço dessa visão onipresente e oportunista é uma multiplicidade de fundamentos para a responsabilização. Explicando melhor: para a indústria da indenização importa obter a indenização e, por isso, importa antes atribuir uma responsabilização que, por sua vez, ao ser alegada em cada caso particular, só se confirmará se houver a adequada fundamentação. Ocorre que a indústria da indenização não parte de um conjunto único e coeso de fundamentos para averiguar e atribuir responsabilizações, porque ela inventa, para efeito de alegar a responsabilização, a fundamentação que pode ser tida como válida naquele momento e naquele campo. Em outras palavras, o que a indústria da indenização realiza é um argumento falacioso: a fim de garantir a validade da conclusão defendida - "cabe a responsabilização neste caso" -, ela inventa a premissa maior, ou seja, o fundamento para a responsabilização. Correto (mais de acordo com uma dedução ou, o que seria suficiente, com uma indução) seria conhecer a premissa geral e verdadeira, isto é, o fundamento para toda responsabilização e, em seguida, comparar essa premissa maior com a menor (o caso particular do dano) e, desse confronto, tirar a conclusão (que antes do confronto não podemos saber qual é). O que faz, ao contrário, a indústria da indenização? Começa já com a conclusão de que "cabe a responsabilização", depois encontra uma premissa menor: "ocorreu este dano concreto que permitirá falar em indenização". Por último, procura uma premissa maior que sirva de regra geral da qual se possa, confrontando-a com a premissa menor, alcançar a conclusão. Esse é um caminho muito comum nas falácias - argumentos logicamente inválidos -, e costuma ser o único instrumento para quem não consegue, ou-não quer, pensar racionalmente.

No entanto, há uma dificuldade que a razão põe em toda essa situação: o que fazer caso não seja possível encontrar a premissa maior? É claro que premissa maior não faltará para quem queira analisar racionalmente qualquer situação, ou seja, não falta regra geral da responsabilidade para quem queira racionalmente averiguar a responsabilização. Mas o que ocorre quando o caçador de indenizações deseja, a todo custo, chegar a uma determinada conclusão, vale dizer, a uma certa responsabilização que garanta, mesmo se não for verdadeira, uma oportuna culpa? Será que existirá premissa geral à mão? Digamos, por exemplo, que quero de toda forma convencer o juiz de que meu vizinho deve pagar a reforma da minha casa inteira (conclusão), uma vez que aconteceu de ele ter pichado o muro da frente da minha casa (premissa menor). Qual premissa maior (ou seja, quid iuris?) deverei comparar com a menor para chegar à minha conclusão? Difícil, senão impossível. A premissa menor, que é o caso concreto, é sempre a realidade mais factual do argumento 
(é o caso concreto), e a conclusão costuma aparecer com clareza (visto que a explicito no argumento), embora não seja evidentemente verdadeira (ao contrário, ela depende de prova); quanto à premissa maior, sua acessibilidade, concretude e racionalidade variam infinitamente, indo do absurdo ao necessário.

Se imaginássemos um caso concreto cuja responsabilização derivasse de obrigação (responsabilidade contratual), ainda poderia ser que uma inversão assim, relacionada à apresentação invertida de premissas, pudesse ser sustentada, pois sempre é possível convencionar tudo o que não seja ilícito ou imoral, por mais excêntrica que fosse referida convenção. Imaginemos, apenas para demonstrar a idéia, uma hipótese em que se pudesse ter razões para crer que o juiz aceitasse uma premissa maior absurda inusitada, por exemplo: "Por convenção, meu vizinho acordou que pagará uma reforma completa da minha casa, caso venha, um dia, a pichar o meu muro da frente". Digamos que exista uma convenção assim, a qual, embora absurda, não é antijurídica, uma vez que estabelece uma obrigação entre as partes. Hipótese inusitada, mas garante, nesse exemplo, a presença de uma premissa maior que, comparada à minha premissa menor ("meu vizinho pichou meu muro"), corrobora a conclusão ("meu vizinho é responsável pelo dano, deve repará-lo na forma da reforma da minha casa"). Isso seria um raciocínio que seria possível organizar e aceitar.

Entretanto, no ambiente da responsabilidade extracontratual, esse processo se passará de distinta forma: a questão argumentativa é exatamente a mesma (premissa maior + premissa menor $=$ conclusão), em que a premissa menor também é um caso concreto e a conclusão é igualmente uma pretendida responsabilização; mas o que é a premissa maior na responsabilidade extracontratual? É o conjunto de responsabilidades já visíveis em direito, seja na forma de responsabilidade subjetiva ou de responsabilidade objetiva. Em resumo: a premissa maior é uma concepção (juridicamente válida) de responsabilidade subjetiva ou de responsabilidade objetiva. Se para o Direito for visível certa concepção de responsabilidade civil, temos, enfim, um princípio geral de responsabilidade civil: uma premissa maior. Se surgir, na experiência humana, um caso concreto que se encaixe naquela concepção geral de responsabilidade civil, temos a premissa menor. E do confronto entre ambas, certamente teremos uma conclusão, mas não necessariamente aquela que desejaríamos como acusadores ou defensores. Ainda de acordo com aquele curioso exemplo do caso dos vizinhos, é possível pensar na mesma premissa menor ("meu vizinho pichou meu muro") e supor a mesma conclusão ("cabe responsabilizá-lo e ele deve reformar minha casa"), mas não se tratando mais de responsabilidade contratual (previamente estipulada por convenção entre as partes), o que se pode colocar no lugar?

Os princípios da responsabilidade civil são visíveis no Direito. O que nosso Direito diz (premissa maior) que possa talvez ser definido como premissa menor? $\mathrm{Na}$ verdade, prevê que se quiséssemos fazer uma espécie de súmula: a) “não se deve causar 
dano a ninguém" (princípio da responsabilidade civil), b) "quem quis causar o dano deve por ele responder" (princípio da responsabilidade civil subjetiva), c) "quem fez o que estava predisposto em lei e apontado como circunstância (de risco) lesiva, deve responder pelo dano que causou" (princípio da responsabilidade civil objetiva).

Assim, indaga-se, em seqüência de raciocínio: a) meu vizinho causou dano a mim? Deve certamente responder. b) Há possibilidades de excluí-lo da responsabilidade? Digamos que não. c) Ele quis causar o dano que causou? Digamos que não, que foi um acidente. Contudo, se o fato estivesse previsto em lei como circunstância de risco passível de causar dano, dar-se-ia a ocorrência da responsabilidade objetiva, acarretando a obrigação legal de responder pelo dano causado. No entanto, o caso simulado não conta com essa previsão legal e não poderá subsumir-se à hipótese de obrigação legal como premissa maior. Portanto, não há premissa maior que possa absorver a pretensão da vítima do muro pichado que desejava ter toda a casa reformada (premissa menor) como indenização pelo dano produzido. Assim, para um raciocínio jurídico racional, não há premissa maior da qual seja possível partir para se chegar àquela conclusão, diante da premissa menor apresentada.

Desse modo, o que temos chamado, neste artigo, de indústria da indenização comporta-se diferentemente do encaminhamento até aqui desenhado por meio da adequação das premissas à busca de uma conclusão segura. Quer dizer, para a indústria da indenização, cujos procedimentos são sistematicamente irracionais, a única saída possível será a de inventar a premissa maior para que dela decorra, por vertentes oblíquas não adequadas nem desejáveis, uma conclusão que possa parecer válida.

Um expediente, então, é criado para inventar a premissa maior que ainda não existe, não importa se por um caminho hermenêutico forçado, se por um caminho tortuoso da doutrina, se pela análise obscura de um julgado anterior, ou se pelas conclusões falaciosas de um parecer especialmente endereçado. Vencendo a falácia, vence, com ela, a injustiça. Por isso, o cuidado que deve ser tomado em circunstâncias assim não é apenas um grande cuidado, mas deve ser, antes de tudo, um cuidado ético. O trajeto perseguido é sedutor e há enorme procura por essas veredas, uma vez que, como já se disse, a indústria da indenização - sem precisar modificar a premissa menor, mas a fim de viabilizar uma conclusão injusta - irracionaliza os fundamentos da responsabilidade civil de forma que uma absurda responsabilização pareça válida. Muito do que se tem chamado hoje de "lógica jurídica" na verdade são instrumentos operando ao gosto dessa máquina abjeta.

A responsabilidade civil não deve se abrir para a deterioração argumentativa e nem precisa dela. Se pretendermos, enquanto juristas democratas, construir uma responsabilidade civil compatível com a democracia, devemos garantir a todo custo que seus princípios, mesmo com as evoluções e mudanças pelas quais deve passar o Direito, se mantenham dentro de um mínimo consistente. Em outras palavras, as mudanças são, sim, 
desejáveis e imprescindíveis, mas desde que se mantenha a consistência do conjunto. Isso não significa ausência de inovações, mas exige a ausência de usurpações da razão. De que razão se fala? Daquela que concebe a vida humana como justa e na qual não pode haver espaço para a usurpação dos princípios da responsabilidade civil.

Será possível evitar essa usurpação em tempos em que, aparentemente, é possível pensar a responsabilização em todo lugar e em todas as áreas jurídicas? Sim, e o caminho para isso é outro princípio: a noção de que a responsabilidade civil é fundada no Direito Civil, e não em outro ramo do Direito. Localizar o centro da responsabilidade civil no Direito Civil envolve indicar, como princípio maior da responsabilidade, a obrigação universal de nos precavermos contra a prática de danos. Encontraremos aplicações dessa máxima e exemplos de desrespeito a ela em todos os ramos do Direito e em todo tempo e lugar. Mas a justificativa para que a máxima exista só no Direito Civil baseia-se no fato de que todos devem se precaver contra a realização de danos a outrem, porque sem isso não há chance de vida civil possível e, em conseqüência, não há nenhum sistema jurídico que possa funcionar adequadamente, seja como concepção de um sistema jurídico, seja como conjunto de instrumentos que dêem conta da repressão e/ou da reparação do desrespeito a essa mesma máxima.

As formas de responsabilidades que estiverem no Direito Penal, no Direito Comercial, nas concepções de direitos difusos (e assim por diante) serão uma derivação não um paralelo ou muito menos a fonte - daquela máxima que nasceu no Direito Civil e é elemento fundador da idéia de sociedade. Sem a prática da precaução, nenhuma sociedade humana se sustenta - e é por isso que o ensino da responsabilidade civil deve, no interior do currículo do Direito Civil, incluir uma profunda reflexão teórica e prática sobre os motivos e os instrumentos de precaução de danos.

O Direito Civil é, inteiro, um sistema de autopreservação da sociedade e, como tal, deve ser mantido e desenvolvido. Nesse contexto, incluem-se medidas contra a usurpação dos próprios fundamentos do Direito Civil e, no caso dos específicos fundamentos da responsabilidade, inclui-se uma luta contra a indústria da indenização que se estabeleceu, mas deve ser duramente combatida. É por isso que a responsabilidade civil faz parte do Direito Civil: para que este não perca sua finalidade civilizatória, dentro dos limites em que um ramo do Direito possa servir de instrumento civilizatório.

5. Por que a responsabilidade civil é uma parte singular do Direito Civil?

Não há como contestar o fato de que a responsabilidade é parte do Direito Civil. O que está em questão, agora, é se a responsabilidade civil é uma parte singular, ou seja, se ela pode ser pensada em uma seção que mereça um capítulo próprio, com conteúdo e sistematicidade suficientes para permitir um estudo isolado das demais áreas do Direito 
Civil e, em conseqüência, permitir a elaboração de autênticos tratados de responsabilidade civil.

Esse é um problema que já pode ser colocado diante da discussão do ensino da responsabilidade civil na graduação. Embora os profissionais do Direito estejam acostumados a consultar os volumes sobre responsabilidade civil reservados nos manuais (o que explicita o fato de que responsabilidade civil é uma parte singular do Direito Civil), já aparece em seu horizonte o peso desse rol bibliográfico que insiste em especificar cada vez mais a responsabilidade. Surgem (e o profissional do Direito os conhece com interesse) inúmeros tratados sobre responsabilidade civil, dispondo sobre as tendências mais atualizadas das conseqüências da responsabilização, dependendo da situação ou do caso concreto.

O aluno de Direito, por exemplo, tende a se acostumar com a idéia de que, uma vez decifrada a base da responsabilidade civil (que para ele seria, muitas vezes, uma fórmula que chega ao cálculo da indenização a partir da constatação do dano), o passo seguinte seria o de conhecer os casos (cases), e quanto mais, melhor. Ele se acostuma, assim, com a idéia de que é possível escrever tratados de responsabilidade civil (cuja finalidade seria apresentar uma coleção de casos concretos e as tendências de solução) e que o aprofundamento do estudo da responsabilidade consiste no acúmulo quantitativo das modalidades de dano e as correspondentes tendências de indenização.

Não há erro na idéia de que a responsabilidade civil é parte singular do Direito Civil. Essa distinção é conferida já no Código Civil, funcionava perfeitamente como tema de capítulos isolados e com mais forte razão é justificativa para a elaboração de volumes exclusivamente dedicados a ela. Só é possível escrever um volume isolado sobre um assunto específico quando este pressupõe uma estrutura tal que contém todos os instrumentos argumentativos necessários, dos princípios gerais às conclusões para cada caso concreto visível ou previsível. Ora, isso pode ser feito também com o tema da responsabilidade civil, ou seja, é possível escrever obra especificamente relacionada a ela.

Ainda, deve ser considerada a diferença entre as duas modalidades de obras dedicadas exclusivamente à responsabilidade civil: a) os volumes de manuais de Direito Civil e b) os tratados específicos. Ao contrário do que se poderia pensar a princípio, os volumes sobre responsabilidade civil integrantes dos manuais acadêmicos de Direito Civil apresentam, diante dos tratados de responsabilidade civil, mais vantagens do que desvantagens do ponto de vista científico e pedagógico (tome-se, por exemplo, a indispensável obra de Caio Mário da Silva Pereira - Responsabilidade Civil-, entre outras que poderiam ser também citadas). Ao mesmo tempo em que explicitam a possibilidade de um estudo concentrado e aprofundado na responsabilidade civil (a ponto de merecer um volume dentro da coleção de Direito Civil), preservam a capacidade de inter-relação 
(e não necessariamente de dependência) com as demais áreas do Direito Civil, uma vez que os fundamentos e regras relacionados às demais áreas estarão plenamente expostos nos outros volumes. Nos tratados de responsabilidade civil não há possibilidade de diálogo claro com outros textos (às vezes, apenas um diálogo sugerido), o que dificulta para o leitor a tarefa de fazer a inevitável ponte entre aquele assunto e outros. Assim, ao menos em termos instrumentais para o estudo da responsabilidade civil na graduação, os manuais, mesmo quando dedicam volumes específicos ao assunto (condição importante para delinear a suficiência do tema como objeto de estudo), explicitam as conexões entre as outras áreas na medida em que se reportam freqüentemente às demais partes do manual. Essa orientação de percurso é fundamental para o estudante, sobretudo quando ele se inicia no conhecimento de determinado tema. Além disso, é igualmente importante para a formação mais segura do profissional do Direito que, mais adiante, se acostumará com a manipulação de obras isoladas e mais pontuais, e poderá sentir muita falta, na prática reflexiva, de um efetivo diálogo dessas obras com outras, da lavra do mesmo Autor, que abordem o Direito Civil como um todo.

Nessa ordem de idéias, a abordagem da responsabilidade civil em manuais de Direito Civil permite uma consistência maior e melhor do que a que se verifica em obras isoladas e verticalizadas (tratados, como poderíamos chamar - em razão da falta de uma melhor denominação) sobre o mesmo assunto. Por quê? Na medida em que consistência é uma inexistência de contradições dentro de um argumento complexo ou de uma extensa compreensão de um tema, um volume sobre responsabilidade civil terá mais chances de escapar das contradições se for pensado efetivamente como uma explicação do tema a partir da racionalidade do próprio tema (a explicação dos casos é compatível com a exposição dos fundamentos e modalidades componentes da teoria da responsabilidade civil).

É claro que o conhecimento dos casos concretos de dano e de indenização é importante já para a formação do acadêmico de Direito, mas sua compreensão restará prejudicada se ele perder de vista a necessidade de consistência do tema e o modo de se bem realizar a sua abordagem. Mesmo uma multiplicidade de casos concretos incompatíveis entre si deve ser consistentemente explicada, e a tendência é que os manuais de Direito Civil consigam cumprir essa função com muito mais competência do que os tratados, os quais têm se tornado cada vez mais coletâneas de julgados sobre a responsabilidade civil, o que pode, em eventuais casos, inviabilizá-los para o trabalho científico da exposição e compreensão do seu objeto.

Finalmente, a estrutura dos volumes dos manuais é tal que exige uma fundamentação consistente do assunto, o que, conseqüentemente, tende a afastá-los da corriqueira tendência a se tornarem acúmulos de julgados. Se for o caso de ampliar ainda mais o tamanho e profundidade desses volumes dos manuais (como a princípio se afirmou), 
tal deve ser resultado não de um acúmulo de julgados, mas, sim, do desenvolvimento dos capítulos da própria teoria geral da responsabilidade civil. Isso justamente porque a responsabilidade civil é parte singular do Direito Civil e tem potencial suficiente para viabilizar o desenvolvimento da sua teoria geral - à qual a solução dos casos deverá se curvar, e não o contrário.

Pode-se ainda dizer que essa tendência dos manuais à sistematicidade confere melhor inteligibilidade à conexão entre a responsabilidade civil e outras áreas do Direito Civil. Assim, o fato de ela ser parte singular tem como corolário não uma independência total das demais áreas, mas uma melhor capacidade de permitir a passagem da compreensão de uma à outra, e, principalmente, da concepção de uma relevância conjunta de ambas. Por exemplo, ao se pensar o que seria uma responsabilidade civil nas relações de família, é preciso igualmente compreender as estruturas do Direito de Família e da responsabilidade civil para depois analisar as possibilidades de sua aproximação, identidade ou oposição. O resultado desse confronto não pode ser uma compreensão artificial do objeto - ainda mais por envolver casos concretos tão relevantes -, e a necessidade acadêmica de compreensão consistente do objeto confere aos manuais de Direito Civil um poder muito maior de compreensão do assunto, tanto no momento do estudo do direito de família quanto no momento do estudo da responsabilidade civil. Os tratados de responsabilidade civil, ao contrário, tendem a perder de vista essa consistência de visão que é imprescindível para o sucesso do encontro entre partes singulares do Direito Civil. Uma inconsistência daí derivada terminará por não explicar a responsabilidade civil no ambiente da família, além de prejudicar os estudos específicos da responsabilidade civil e do direito de família, o que é um grande risco.

Percebe-se, indiretamente, que aqui se faz uma crítica aos tratados de responsabilidade civil. Na verdade, trata-se da constatação de uma falha em nossa atual tratadística, que no caso da responsabilidade civil tende a, como antes mencionado, investir na coletânea de casos concretos e respectivos julgados aplicáveis ou paradigmáticos. Esse acúmulo quantitativo de casos concretos e também de explicações teóricas da responsabilidade pode significar, na verdade, a falta qualitativa de algo aqui apontado como fundamental para o ensino da responsabilidade civil na graduação: a consistência. Não necessariamente um manual de Direito Civil será melhor do que um tratado de responsabilidade civil na tarefa de explicar os fundamentos da responsabilidade, mas as chances de perder de vista a consistência nos tratados é consideravelmente maior. Como explicar, então, o tamanho êxito científico e filosófico de certos tratados, a exemplo do inigualável Tratado de direito privado, de Pontes de Miranda? Esse é um exemplo de consistência na obra, de fato, que reflete, todavia, o mais importante: a consistência do pensamento do próprio Autor. O Tratado de direito privado, de Pontes de Miranda, não foi concebido para ser uma coletânea de casos concretos e seus julgados, mas, sim, uma 
gigantesca obra explicativa das instituições do Direito Civil. Dada a positiva prolificidade de seu Autor, essa obra tornou-se relevante e é exemplo de um ideal de formação que se espera atingir de fato um dia: ela foi pensada mais para os estudiosos do Direito do que para os operadores do direito, daí sua ênfase na análise e na explicação aprofundada dos institutos. Por ser ela um exemplo de consistência e de pleno cumprimento do ideal de compreensão didática de seu tema, merece com letras maiúsculas a denominação de Tratado.

O que importa, afinal, não é o tamanho do volume que explica a responsabilidade civil, mas, sim, se, independentemente do tamanho alcançado e da metodologia escolhida, ele cumpre devidamente a finalidade pedagógica do ensino em uma graduação de qualidade. Os textos utilizados como guia para o estudo da responsabilidade civil, como uma parte singular do Direito Civil, devem não apenas ser competentes na apresentação da teoria geral da responsabilidade, mas devem, principalmente, apresentar ao acadêmico as pontes existentes entre a responsabilidade civil e outras áreas, sem permitir que o leitor seja ludibriado por acoplagens artificiais. Devem permitir ainda que o estudante se torne capacitado a lidar com o conhecimento dos casos concretos e com o reconhecimento das soluções judiciais válidas em nosso Direito. Tudo isso sem consentir, contudo, que o estudioso se torne apenas mais uma parte na odiosa engrenagem da indústria da indenização.

Por uma questão estrutural, os manuais (de uso acadêmico) têm melhores condições de cumprir a função dos tratados tradicionais (explicar um tema de forma didática, com consistência e suficiência), ao mesmo tempo em que os tratados atuais, na verdade muitas vezes compêndios que visam ser manuais (de uso profissional), bem mereceriam investir na recuperação da sua própria viabilidade didática perante os alunos da graduação. Certamente, os próprios profissionais do Direito sairiam ganhando com isso, quem sabe a ponto de ler também o Tratado (a enciclopédia?), de Pontes de Miranda.

6. Por que a responsabilidade civil é uma parte do Direito Civil tão importante quanto as demais?

Volumes exclusivamente dedicados à responsabilidade civil parecem explicitar a suficiência desta como parte singular do Direito Civil, mas, se tomarmos os manuais de Direito Civil (em que aparecem lado a lado todas as partes singulares do Direito Civil ou, ao menos, as reconhecidamente mais importantes), por que em alguns casos a responsabilidade ocupa o menor volume? Será isso indicação de que ela é menos importante do que as demais? Não mereceria ser tida como igualmente importante, uma vez que, inclusive, pode ser reconhecida como parte singular? 
A imagem da ligeireza do volume da responsabilidade civil, em comparação com os demais volumes que integram os manuais, é, na verdade, a ilustração de uma noção que ainda se apresenta entre nós, autores ou estudantes: parece que, em termos de teoria geral, a responsabilidade não é tão bem nutrida (ou tão densa) quanto podem sê-lo as demais subáreas. Tanto é verdade que, quando ocorre de um volume sobre responsabilidade civil alcançar uma densidade considerável, isso se deve à já decantada prática da coleção de casos e jurisprudência. E como o conteúdo a ser transmitido no momento primeiro do estudo do Direito - no Brasil de hoje, a graduação ${ }^{1}$ - deve ser principalmente constituído de teoria e reflexão sobre o assunto, o repertório da responsabilidade civil em termos de teoria geral parece não ser páreo para as teorias gerais das outras áreas: ela perde fácil para a teoria do direito de família, a teoria das sucessões, a teoria das obrigações, a teoria dos contratos e assim por diante. Talvez perca até para a teoria geral dos chamados microssistemas ou dos direitos difusos que têm relevância ou repercussão no Direito Civil, a exemplo do direito do consumidor e do direito ambiental. De fato, tem sido assim; mas por quê? Será por uma característica estrutural do próprio assunto? Por falta de inspiração dos pensadores da responsabilidade civil?

Na verdade, essa carestia de repertório na parte teórica dos manuais e tratados de responsabilidade civil é representativa da nossa falta de costume em refletir a respeito da responsabilidade. Sim: ela é um campo teórico ainda em aberto, cujo alcance ainda deve ser investigado e desenvolvido. Nós até podemos manter nossa tendência muito bem recebida de coligir casos concretos e jurisprudência, mas é uma lacuna impressionante não investirmos no desenvolvimento da teoria geral da responsabilidade, e mesmo em uma teoria especial.

Com isso não se quer dizer, é claro, que são irrelevantes os inúmeros estudos monográficos dedicados à responsabilidade civil, sob a forma de tratados, teses, ensaios, artigos e seus símiles. Contudo, o fato é que esse rol gigantesco de obras sobre a responsabilidade civil não necessariamente tem levado à elaboração de uma teoria geral mais avançada sobre o assunto. A missão do Autor jurídico, quando se dedica a enfrentar analiticamente um tema, não é apenas contribuir para a ampliação quantitativa das opiniões já existentes (tarefa legítima, porém secundária), mas contribuir especialmente para definir ou redefinir as condições para a elaboração de uma teoria geral, que permita manter o máximo possível de consistência no conjunto das visões doutrinárias. Não se trata de contribuir para a construção de um universo dogmático, em que todas as opiniões manifestadas sejam iguais ou conformes ao cânone sagrado, mas certamente de não transformar a multiplicidade de visões em um vale-tudo irracionalista, no qual se perdem

\footnotetext{
Referimô-nos aqui dessa forma porque ainda haverá um momento em que, no Brasil, o primeiro contato com o estudo do direito será no ensino fundamental. Quiçá.
} 
de vista os fundamentos gerais da responsabilidade civil - ou se acaba mesmo por destruílos. O resultado será o fortalecimento da prática já denunciada da indústria da indenização e a intensificação da névoa que, diante dos acadêmicos de direito, cobre os princípios da responsabilidade civil.

O cada vez mais amplificado universo de estudos sobre a responsabilidade civil no país indica, sim, que o assunto requer muita atenção, mas é curioso notar que a quase totalidade dos textos dedicados à responsabilidade tem interesse específico em determinados casos concretos e acabam também por interessar mais aos profissionais do que aos estudantes de Direito. Considerando que os estudos doutrinais devem ter preocupação ou direcionamento acadêmico, estamos diante de um paradoxo: por que motivo uma tese, por exemplo, modelada segundo regras formalmente acadêmicas, acabaria por merecer mais interesse dos profissionais do que dos próprios acadêmicos? Resposta: porque ela se dirige aos profissionais, e não aos acadêmicos. E por que não a estes (ou também a estes)? Porque não está no centro da tese, normalmente, uma preocupação em refletir sobre os fundamentos da responsabilidade civil (sobre o cerne da teoria geral, portanto), mas, sim, em acrescentar mais terminações à cadeia de aplicações práticas do direito dos danos.

Esse apego às preocupações práticas, em si, não é bom nem ruim, mas será péssimo, pelo ângulo acadêmico, se representar a única finalidade de pesquisa válida para nossos graduandos e pós-graduandos. Na prática, como sabemos, a "tendência" tem sido esta: concentrar a pesquisa em temas que possam, adiante, fornecer novas soluções para novos casos concretos que já se verificam. Por que não, todavia, investigar as fundações da responsabilidade civil, de maneira a alcançar ou melhorar as fórmulas que já foram descobertas e poderiam ser aplicadas a quaisquer novos casos? Por se afastarem desse tipo de investigação, as pesquisas jurídicas acadêmicas (da iniciação científica ao mestrado e ao doutorado) têm, na prática, pouca contribuição a trazer ao estudo fundamental da responsabilidade. Deveria ser o contrário, mas definitivamente não estamos em um universo acadêmico que favoreça as trocas científicas e acadêmicas; ao contrário, favorece-se a disputa pela solução prática imediata. Ideal e perfeitamente realizável seria a conjugação dos interesses práticos da escrita acadêmica sobre a responsabilidade civil (escrita que muito contribui para a definição dos alcances dessa área singular do Direito Civil, tão importante quanto as outras) com as necessidades intelectuais e pedagógicas dos estudantes que se iniciam no estudo do Direito (ou seja, os graduandos). Na medida em que os textos doutrinários perdem o empenho pedagógico (que inclui a necessidade de dar conta da tarefa de elaboração de um manual ou de um tratado - no sentido clássico do termo), eles demonstram uma grande dificuldade em contribuir para aquela parte da teoria da responsabilidade civil que mais carece de opiniões bem embasadas: a teoria geral da responsabilidade. Consideremos os textos que têm sido defendidos e publicados nestes últimos meses ou mesmo anos sobre a responsabilidade civil: qual a porcentagem 
daqueles que centram seu interesse na reflexão sobre os fundamentos da responsabilidade, em lugar de partir imediatamente para as aplicações práticas do arsenal jurídico do nosso direito dos danos? Trata-se certamente de uma parcela muito módica. Faltam reflexões aprofundadas sobre os fundamentos da responsabilidade, mesmo quando for o caso de pensarmos soluções práticas para casos concretos.

Nota-se que o aluno da graduação se perde facilmente diante dessa miríade de teses sobre as soluções válidas para cada caso. Ao final do confronto de tantas soluções práticas (muitas delas sabidamente contraditórias, expondo o aspecto um tanto lotérico de certas decisões judiciais), é difícil estabelecer ou manter uma visão consistente para todo o conjunto. E, ainda que seja impossível e também desnecessário chegar a um consenso intelectual sobre todas as questões que envolvem a responsabilidade, é preciso certamente haver um solo doutrinário e conceitual comum, para que sempre falemos a mesma língua ao tratar da responsabilidade. Do contrário, se perderá a oportunidade de fazer evoluir a teoria da responsabilidade civil também enquanto um diálogo entre os autores, bem como a oportunidade de construir uma prática de fortalecimento da teoria geral da responsabilidade civil (e do próprio Direito Civil).

O elo para todas as diversas opiniões em torno da responsabilidade civil é a sua teoria geral, e ela deve ser profundamente estudada. Em lugar de prontamente lançar o graduando em Direito no ânimo do cálculo indenizatório, é fundamental fortalecer a sua própria reflexão em torno dos fundamentos e dos elementos da responsabilidade. Isso envolve, inclusive, a reflexão a respeito da relação da responsabilidade civil com outras áreas do Direito e, o que é mais rico, um contato direto com o mundo da prática visível em outras ciências e humanidades. O estudo aprofundado da teoria geral da responsabilidade civil é a melhor maneira de evidenciar por que o direito dos danos é uma parte do Direito Civil tão importante quanto as demais: ele tem uma multiplicidade de questões conceituais muito importantes a serem deslindadas, principalmente hoje, em que prolifera a tendência de deixar para trás o quanto antes a teoria geral ou, ao menos, menosprezar a sua validade. E é exatamente o contrário que deve ser feito!

A verdadeira chave para a construção de um tratado ou de um manual de Direito Civil que obtenha êxito universal é ser igualmente acessível a acadêmicos e a profissionais: se pensarmos que deve haver uma diferença de nível entre os textos voltados para as diferentes categorias, contribuiremos para essa cisão indesejável entre textos de iniciação (ditos "manuais", que simplificam a reflexão e obrigam à padronização do pensamento do graduando, quando deveriam ser Tratados que convidam à reflexão e preparam para a autenticidade do pensamento do leitor) e textos de aplicação prática (ditos "tratados", que padronizam os casos e fomentam a prática da falácia, quando deveriam ser Manuais que recordam a técnica àquele que já a conhece, e recomendam ao seu utilizador o retorno, para atualização e reflexão, aos Tratados). 
Em outras palavras, manuais e tratados não nos faltam, mas eles, muitas vezes, trocam de papéis: nossos manuais se voltam para os estudantes, quando deveriam se voltar para os profissionais sem afastá-los da reflexão, e nossos tratados se voltam para os profissionais, quando deveriam se voltar para os estudantes sem afundá-los em uma concepção pragmática de mundo. Com certeza, um real desenvolvimento sistêmico da teoria geral da responsabilidade civil permitiria preparar novos estudantes melhor municiados para a reflexão racional dos fundamentos do direito, bem como uma aplicação prática das suas soluções sem necessariamente recorrer à indústria da indenização. Ao contrário, enquanto esse empenho em fortalecer a teoria geral não se verificar, o potencial da responsabilidade civil em se mostrar área tão importante quanto as demais poderá se enfraquecer, oprimido pelo peso da quantidade gigantesca de casos concretos que estamos todos acostumados a coligir quando preparamos para publicação nossos textos sobre a responsabilidade.

7. A responsabilidade civil pode se tornar uma parte do Direito Civil mais importante do que as demais?

O propósito desta pergunta é essencialmente acadêmico. Evidentemente, a responsabilidade civil é uma parte singular e tem tanta valia quanto as demais, mas será que haveria motivos acadêmicos ou intelectuais para colocá-la em lugar de destaque no interior do sistema do Direito Civil? Seria possível fazer com que a responsabilidade civil passasse da posição de pouco destaque que tem, para uma posição mais central na concepção do universo do Direito Civil?

Por que essa seria uma questão relevante? Porque em qualquer sistema científico ou técnico em que se identifiquem seções ou partes (de estudo) constituintes, é importante ordenar essas partes para que não nos percamos no estudo do sistema como um todo (e também em cada parte em particular). Não é por acaso que existe certa ordem das matérias na definição dos assuntos em um código, em uma lei e em um manual ou tratado: o conhecimento daquele assunto exige que passemos por certas etapas. Assim, da mesma maneira que devemos identificar os elementos constituintes de uma área do conhecimento, precisamos igualmente determinar a melhor ordem para conhecer e estudar esses elementos. A finalidade é prática, portanto: é uma finalidade didática. Diante da questão do ensino da responsabilidade na graduação, deve-se verificar qual a finalidade pedagógica: formar para a indústria da indenização ou formar para a prática da precaução? Dependendo da resposta, o lugar do direito dos danos na fila das matérias do Direito Civil pode mudar.

Trata-se de uma questão que, em termos práticos, costuma aparecer para nós como já resolvida, uma vez que, ao menos no que diz respeito à separação dos assuntos e à disposição da sua ordem de apresentação, parece já existir certo consenso. Acreditamos, na 
verdade, que em lugar de consenso o que há é tradição: afinal, tanto não nos questionamos a fundo sobre a viabilidade de uma reformulação na disposição das matérias do Direito Civil quanto o esquema há décadas em funcionamento parece funcionar muito bem, seja em termos pedagógicos, seja em termos operativos. No entanto, há um preço: justamente pela tradição consagrada dessa divisão das matérias do Direito Civil, é muito difícil achar espaço para nela incluir os microssistemas do Direito Civil e os estudos interdisciplinares, o que dá equivocadamente a entender que tais seções são secundárias. Esse sempre foi o caso da responsabilidade civil antes que ela ganhasse espaço em volumes específicos dos manuais (tratados?) de Direito Civil.

Ora, assim como a responsabilidade já conquistou esse espaço diante das divisões mais tradicionais, o mesmo caso pode acontecer com outras seções (principalmente direito do consumidor). Uma das conseqüências é a ampliação do já extenso programa da disciplina de Direito Civil, que tende a atravessar todo o curso de graduação em Direito. Entretanto, há dois problemas: nem sempre toda a teoria do Direito Civil consegue ser passada no espaço disponível do curso de graduação, bem como nem sempre se sabe qual o melhor momento de apresentar os temas que antigamente eram secundários e agora merecem atenção singular, visto que são partes singulares do Direito Civil.

A respeito do primeiro problema (muito grave), a melhor solução prática já pode ser percebida, como a ampliação da carga horária do Direito Civil na graduação, mas o fato é que um grande número de cursos de graduação em direito dificilmente ultrapassa o piso de horas-aula e - o que é muito preocupante - tende a ignorar certas seções do Direito Civil (por exemplo, teoria dos contratos, que na maioria das vezes "não cabe" no programa de teoria das obrigações de muitas faculdades, e o graduando conclui o curso sem ter sido iniciado atentamente nessa área). Em relação ao segundo problema, a dificuldade de localizar determinado assunto na grade curricular é sentida com peso ainda maior pelo aluno, e não pelos professores, uma vez que será ele quem se perderá diante da tarefa de estabelecer as conexões daquele inóspito assunto com os outros que necessariamente aprendeu a dominar.

Os diferentes conteúdos de um mesmo tema jurídico têm, sim, desigual importância em função da concepção pedagógica do curso de Direito Civil. Tal valoração, justamente por esse critério, não é inflexível, mas deve ser considerada e merece ser explicitada pelos doutrinadores. O aluno da graduação necessita ser informado do que é mais, ou menos, importante entre as disciplinas do Direito Civil, deve ser orientado sobre quais são os melhores autores e quais são as teses interessantes que merecem consideração. Tudo isso é fundamental para que ele perceba que o estudo do Direito Civil não necessita ser um estudo maçante, mas, sim, o reflexo de uma visão dinâmica do sistema civilista que cada jurista, cada operador e cada estudante pode perfeitamente desenvolver. 
Com certeza é possível instigar nos alunos um maior interesse pelo assunto, e igualmente um interesse ainda maior por assuntos que (não importa o motivo) mereçam maior atenção. Assim, no que diz respeito à disposição das disciplinas do Direito Civil, não há por que fugir da ordem delas - tal como aparecem no Código Civil -, mas há razões consideráveis para ampliar o alcance de cada um dos momentos dessa ordenação. Em outras palavras, cada parte singular do Direito Civil (dos manuais, dos tratados, do estudo, enfim, do Direito Civil) deve dialogar com as outras, assim como deve dialogar com outras áreas do Direito, para que se perceba, com precisão e graças a esse contato, a importância específica que cada área possui. É muito comum que o aluno - e mais ainda o professor - tenha interesse ou vocação para uma área ou até para um tema específico (por exemplo, responsabilidade civil), e é igualmente comum que ele se sinta distante das demais áreas (mesmo que estas constituam a maioria do conteúdo do seu curso de Direito). Contudo, entre as várias maneiras de despertar a curiosidade e o interesse do aluno pelas demais áreas, está a estratégia (absolutamente honesta em termos pedagógicos) de fazer a ponte prática e teórica entre o seu assunto de preferência e outros assuntos; ou por outra via (ainda melhor), entre o assunto que ora se estuda por obrigação e aquelas questões que pessoalmente mais interessam ao aluno. É sempre possível mostrar que um dos elementos determinantes da importância do assunto que se estuda é o seu potencial para dialogar com o tema que intimamente mais nos interessa. Nesse sentido, quanto maior esse potencial para dialogar com outros assuntos, maior a sua importância dentro do sistema do Direito Civil.

Sendo este o critério da importância de um tema ou área, o que pode ser dito da responsabilidade civil? A despeito de ter sido por tanto tempo relegada a um plano secundário, a responsabilidade civil é uma das áreas que mais relações apresenta com outras. É muito fácil encontrar acadêmicos interessados na responsabilidade civil como um dos seus temas centrais, e é quase impossível não encontrar uma vinculação da área que particularmente nos interessa com a responsabilidade civil. Isso serve para mostrar que o direito dos danos tem uma grande importância como tema de estudo do Direito Civil, mesmo que seja preciso determinar qual a sua posição no ranque. É válida, de qualquer maneira, a atenção para a necessidade prática da interdisciplinaridade na prática pedagógica. Os alunos de graduação sempre sentem muita falta dessa atuação interdisciplinar e interdepartamental, e sua pessoal dificuldade em aliar o conteúdo de uma área ao de outra é, muitas vezes, manifesta. Cabe aos autores e professores, mesmo quando encarregados de um tema específico, esforçarem-se por dar conta daquele conteúdo, mas, principalmente, cabe a eles procurarem estabelecer ligações com outras áreas e momentos do curso, sob pena de congelar o pensamento e impossibilitar a reflexão.

Não há fórmula mágica para essa postura interdisciplinar, mas é certo que se trata de uma atitude por parte de quem leciona e de quem estuda. Perder essa oportunidade 
no momento da graduação pode ser fatal para as vocações intelectuais e profissionais dos alunos, uma vez que muitas carreiras são definidas a partir do momento em que a curiosidade lhes permite conhecer assuntos ou áreas que não estão sob o peso opressor das provas e avaliações. Nesse panorama, a responsabilidade civil é particularmente privilegiada. Justamente por sempre conter um dos princípios fundamentais do Direito - não causar dano a ninguém -, ela está praticamente presente em todos os momentos, mesmo que em potencial. É quase impossível não conceber uma situação de dano, ocorrido ou potencial, em qualquer área. Isso significa o quê? Para a perspectiva indenizatória, especificamente, significa a possibilidade de propor indenizações em todos os campos. Para a perspectiva reflexiva, significa a possibilidade, desde logo, de refletir a obrigação em todos os campos, de operar pela precaução e pela prevenção. Para as demais perspectivas, representa, enfim, uma possibilidade infinita de associações com outras áreas.

Desse ponto de vista, a responsabilidade civil merece ser apresentada ao aluno como um instrumento sempre à mão para o estudo do Direito Civil e do Direito como um todo. Justamente por isso, interessante seria que o aluno da graduação não fosse apresentado a ela no final do curso, mas, sim, no início e, em especial, com a teoria das obrigações, visto que as duas áreas (obrigações e responsabilidade) caminham lado a lado. De fato, se considerarmos exclusivamente as divisões do Direito Civil, a teoria geral da responsabilidade civil se aproxima muito da lógica que rege a teoria da inexecução das obrigações: se há dano e há culpa, deve haver indenização. Ora, isso torna muito oportuno ilustrar os alcances de uma área também com o que se passa na outra. Nesse caso específico, serve para mostrar ao aluno da graduação (e para recordar ao pós-graduando ou ao profissional) que, tanto em um caso como no outro, a ênfase no cálculo indenizatório é uma inversão de valores na concepção do próprio sentido do Direito Civil.

Posto isso, é possível dizer que a responsabilidade civil pode ser, sim, a parte singular superior por excelência no sistema pedagógico do Direito Civil, desde que cumpra aquela tarefa intelectual de bem desenvolver, de forma consistente, a sua teoria geral. Há toda uma teoria geral da responsabilidade que deve expor exatamente esses instrumentos de interdisciplinaridade, e os resultados dessa reflexão certamente levarão a uma revisão da própria figura do cidadão, do cives, aquele em torno de quem se constrói todo Direito Civil.

Os antigos tinham, aparentemente, uma noção de cidadania mais concreta do que a que circula entre nós hoje. Para eles (a exemplo dos sempre recordados romanos), ser cidadão era estar de acordo com certas regras sociais que faziam sentido porque garantiam um ideal jurídico e político de liberdade; ser cidadão era, entre outros aspectos, ter o que é seu e respeitar o que é dos outros, mas, principalmente, fazê-lo por saber do benefício que a preservação patrimonial trazia para todos, e não por medo de sanção. Em outras palavras, havia um sentido clássico da cidadania que consistia em agir em favor da 
coesão social, e não em função de temores pessoais diante do poder soberano. De acordo com os princípios da responsabilidade civil, sabia-se que não se deve causar dano ao outro porque isso é uma violência contra a própria civitas.

Cumpre recuperar esse significado hoje. É fundamental mostrar que a responsabilidade civil pode ser uma forma de analisar o Direito Civil como um instrumento de fortalecimento entre os cidadãos. Ao contrário, enquanto deixarmos prevalecer a indústria da indenização - que se esforça por enfraquecer o vínculo entre os cidadãos -, contribuiremos não apenas para uma visão paupérrima do direito dos danos, como também para o enfraquecimento do próprio sistema do Direito Civil.

8. Por que todos esses aspectos são relevantes para o ensino do Direito Civil na graduação?

Uma discussão sobre o ensino da responsabilidade civil na graduação tenderia, em vista do atual panorama do ensino superior no Brasil, a apresentar sugestões sobre como melhor aproveitar as novas criações, em termos de desfechos indenizatórios.

Por isso, uma discussão sobre o ensino da graduação no Brasil deve, necessariamente, considerar que estamos imersos em um ambiente muito insatisfatório para a universidade, que é preciso lutar pela retomada do valor do ensino universitário e que isso pressupõe não nos entregarmos à banalização do pensamento jurídico, mas, ao contrário, tratá-lo com a ênfase científica e interdisciplinar que sempre requereu e nem sempre teve. No caso do ensino universitário, a sua primordial finalidade não deveria ser, jamais, a de se entregar aos desejos do mercado; tomemos isso como um pressuposto, pois é uma indignidade ter de justificar a validade do próprio ensino universitário para além das demandas do mercado!

Quando nos propomos travar uma discussão do ensino da responsabilidade civil na graduação, trata-se, pois, de desenvolver uma discussão fundada exclusivamente em um ideal de excelência universitária. Busca-se, assim, explicitar que o ensino da responsabilidade civil deve expressar um ideal de universidade, o qual tem sido muito comprometido, infelizmente, pelo fato de se valorizar mais aquela perspectiva simplesmente indenizatória, colocada na dianteira do ensino quase que exclusivamente.

O direito dos danos, na graduação, é uma preciosa oportunidade para se desenvolver uma concepção de cidadania voltada para a precaução e a prevenção - para o fortalecimento da vida social, portanto. Além disso, sua reflexão nesse sentido é muito profícua para a formação intelectual do acadêmico de Direito, ou seja, o ensino reflexivo da responsabilidade pode mostrar que todo o Direito Civil se beneficiaria de uma perspectiva crítica, com grande ênfase no aprendizado teórico. Essa ênfase não implicará a perda no alcance técnico do curso nem a diminuição na capacidade de auto-informação do próprio 
aluno a respeito das inovações judiciais em matéria de direito dos danos, mas, certamente, implicará a necessidade de uma tomada de posição em termos de política universitária por parte da coordenação de cada curso de Direito.

O que se propôs aqui, entre outras questões, foi a reformulação da estrutura dos manuais ou tratados de Direito Civil de maneira tanto a aprimorar o conhecimento crítico do assunto quanto a viabilizar uma reorganização sistemática do próprio direito dos danos. Nada disso funcionará, todavia, se faltar proatividade da parte dos próprios departamentos de Direito Civil, de modo que a maior de todas as dificuldades a ser enfrentada por qualquer projeto de reformulação ou retomada da excelência universitária está logo no início, na conquista do apoio institucional necessário para o trabalho do professor. Trata-se, assim, de se discutir política universitária e políticas de proatividade acadêmica que garantam aos professores os meios necessários para experimentar, com os alunos da graduação, os novos meios de discussão do Direito Civil, os quais podem permitir o desenvolvimento de um ensino jurídico mais rico, dinâmico e criativo, isto é, academicamente diferenciado. $\mathrm{O}$ que pode tornar menos atraente o ensino universitário do Direito Civil não é o fato de ser universitário, e sim o fato de não ser participativo ou encantador; todavia, se pensarmos que o caminho para essa participação e para esse encantamento seja a redução da formação a uma simples etapa equivalente à preparação para concursos futuros, então já se terá perdido de vista a finalidade da qualidade.

Chegou-se a esse assunto por meio da responsabilidade civil, mas o ponto de partida poderia ter sido qualquer outro no interior do Direito Civil. Nessa ordem de idéias, insistimos no caráter oportuno da responsabilidade civil, que representa tão bem tudo o que o ensino do Direito Civil pode ser (um ensino de excelência acadêmica, porque fundado na reflexão participativa e voltado para a formação crítica), ao mesmo tempo em que indica claramente o lado negro para o qual ele tende (em razão da perspectiva indenizatória já mencionada e que tem aproximações com todas as áreas do Direito Civil, ou mesmo do direito em geral). $\mathrm{O}$ que foi dito até aqui em torno da responsabilidade civil pode, com as devidas modificações, ser estendido para as outras áreas do Direito Civil e, principalmente, serve como ponto de referência para uma reflexão direta sobre o ensino do Direito Civil.

Poder-se-ia mesmo dizer que há duas modalidades de ensino do Direito Civil na graduação que correspondem aproximativamente àquelas duas modalidades em torno da responsabilidade civil (indenizatória e reflexiva): um paradigma de espetáculo e um paradigma de discussão. Embora essas duas palavras - espetáculo e discussão tenham, no uso comum, respectivamente uma acepção positiva e negativa, na verdade cada uma delas pode ser positiva e negativa, mas é pertinente ressaltar aqui o que têm respectivamente de negativo e positivo. 
Trata-se de dois grandes paradigmas para o ensino do Direito Civil: um negativamente espetacular e outro positivamente polêmico.

O paradigma espetacular é aquele segundo o qual as aulas de Direito Civil devem se converter em um espetáculo para o entretenimento da platéia de estudantes, cuja atenção parece ser reconquistada a cada minuto pelo professor-apresentador, que, para isso, deve se concentrar em desenvolver técnicas de atratividade constante. $\mathrm{O}$ alunado que se acostuma a esse tipo de docência passa a ver a si mesmo como público e, uma vez assumida essa sua máscara coletiva, passa a se impor como público consumidor, estabelecendo com o professor-apresentador uma relação de dominação, por meio da exigência de determinado produto pelo qual paga. É esse o modelo menos tradicional (ao menos em cursos de Direito) da relação entre professor e aluno, formulando um paradigma no qual o público consumidor, constituído pelos alunos, passa, ao estudar a responsabilidade civil, a exigir fórmulas imediatamente aplicáveis de comprovação da responsabilidade e da fixação do cálculo indenizatório. Não aparece, e também não se discute, a questão do bem jurídico original em si mesmo.

Quanto ao paradigma polêmico, é aquele segundo o qual as aulas de Direito Civil devem se conduzir na forma de um foro para a livre discussão entre professores e estudantes, cujas idéias devem ser convidadas constantemente a se manifestar e se confrontar, em um processo em que o professor deve, como um mediador em uma ágora, empenhar-se na garantia do direito de manifestação. $\mathrm{O}$ alunado que é apresentado a esse tipo de docência passa a ver a si mesmo como partícipe social e, uma vez assumida essa sua máscara coletiva, passa a se impor como se fosse um agente público, digamos assim, estabelecendo com o professor-mediador uma relação de descoberta por meio da discussão livre das minúcias do seu tema. É esse o modelo democrático da relação entre professores e alunos. E, nesse paradigma, o agente público constituído pelos alunos pode, ao estudar a responsabilidade civil, ter acesso direto à reflexão sobre o bem jurídico envolvido, constituindo uma consideração aprofundada sobre as bases teóricas da responsabilidade civil antes de lidar com as técnicas pragmáticas, mas secundárias, da proporcionalidade entre dano causado e indenização devida.

E se o ensino não for nem espetacular nem polêmico? Então, é sinal de que nem é ensino, mas provavelmente uma mera condução dogmática de conteúdo. É pertinente lembrar que em um caso em que a relação entre professores e alunos seja ruim, no sentido de que é autoritária e não-participativa, não necessariamente estamos fora do paradigma espetacular, cujo espetáculo pode ser exatamente o do autoritarismo. No entanto, certamente estaremos fora de um paradigma polêmico, porque a base da polêmica é o democrático direito da isegoria, isto é, igual direito de falar.

Pode parecer incômodo ver negatividade no espetáculo (que delicia a tantos jovens hoje em dia) ou, principalmente, positividade na polêmica (que é vulgarmente vista 
como algo impertinente), mas a polêmica é uma prática que falta na prática do ensino do Direito Civil e, com mais forte razão, no da responsabilidade civil. O direito dos danos tem passado, nestas últimas décadas, por evoluções consideráveis, a ponto mesmo de se observar uma crise na noção clássica de responsabilidade e se criar uma outra concepção de responsabilidade que melhor responda às atuais demandas por justiça social e justiça civil. Contudo, é uma evolução que não é tão evidente por si mesma, tanto que tende a ser acessível apenas a quem atente à discussão da teoria geral da responsabilidade civil. A perspectiva indenizatória, pode não se acreditar - uma vez que teria muitas formas de se beneficiar das novas soluções possibilitadas pela responsabilidade objetiva -, é um meio muito eficaz de preservação da concepção clássica da responsabilidade subjetiva. E é uma consideração polêmica do direito dos danos que melhor permite ver todo o alcance e todo o valor da concepção da responsabilidade objetiva como solo primordial da responsabilização atualmente.

O Direito Civil sempre sairá com reduções a cada situação em que for seduzido pelos ardis do paradigma do espetáculo. E sempre enterrará as suas reais oportunidades de desenvolvimento ou evolução intelectual a cada momento em que recusar experimentar algum procedimento polêmico. Como poderemos formar juristas conscientes do valor do próprio Direito Civil se não lhes ensinamos a refletir e a ousar, questionando as fórmulas prontas? A responsabilidade civil é um campo mais do que propício para se tentar essa experimentação ou essa mudança paradigmática, uma vez que já somos, infelizmente, convidados a antecipar os cálculos indenizatórios, deixando de lado, o quanto antes, a reflexão em torno do bem jurídico. Por quê? Para quê? O ideal seria encontrar estratégias não de encantamento de um público consumidor que oprime a nós, professores, nem estratégias de bajulação acerca de professores que oprimem a nós, alunos, mas construir ambientes propícios à discussão, ao debate e a todas as práticas da polêmica - única situação que de fato pode trazer esclarecimento doutrinário e enriquecimento intelectual. $\mathrm{O}$ uso de técnicas e fórmulas que permitam chegar à indenização ainda é uma questão secundária. Antes precisamos recuperar universalmente o sentido da responsabilidade civil, e talvez, por meio dela, o sentido do Direito Civil como um todo. Sem esse luminar ou norte, o caminho para a descoberta e criação de novas e autênticas soluções jurídicas pode se tornar um labirinto que não nos levará a lugar algum.

9. O que significará, consideradas essas proposições, o ensino da responsabilidade civil na graduação?

De acordo com o que já foi exposto, pensamos ser necessário, portanto, dar um salto no ensino da responsabilidade civil. 
É preciso criar o espaço para o direito dos danos nos cursos em que ele não existe na grade curricular e, nos quais já existir, é preciso mudar o sistema pedagógico por meio da experimentação de estratégias de discussão coletivas do sentido social da preservação dos bens e do patrimônio. O estudo da responsabilidade civil é oportunidade única para estabelecer uma rica relação interseccional entre as diversas partes do Direito Civil e interdisciplinar entre o Direito Civil e as demais áreas jurídicas. É, finalmente, um instrumento de ingresso do pensamento jurídico no conjunto dos problemas das ciências humanas, e com elas ele pode tanto dialogar quanto confrontar-se.

Que tipo de responsabilidade civil pode-se conceber na sociedade brasileira?

Eis uma pergunta cuja pertinência é inegável, visto que todas as nossas fórmulas de responsabilização costumam vir de outras sociedades e países - até de outros sistemas jurídicos -, e não costumamos ver problema em aplicá-las aqui como se não tivessem origem em uma outra concepção de sociedade e dentro de um outro universo de possibilidades sociais. Essa é uma questão exemplar entre aquelas que faltam ser conduzidas com profundidade no nosso debate jurídico brasileiro: qual é a especificidade que deve ter - e ainda não tem - o direito dos danos no Brasil, em vista do tipo de sociedades que formamos e das dificuldades e desigualdades que mantemos? Faz sentido pensar a responsabilização objetiva, por exemplo, em uma sociedade que não é nem a francesa nem a norte-americana? O "sim" como resposta a essa questão não é tão evidente assim, e gostaríamos de assistir a um amplo debate sobre esse assunto.

Pode-se fazer do Brasil, ao mesmo tempo, um exemplo para outras nações de responsabilização, principalmente social ou ambiental? Uma vez que a responsabilidade se define a partir, basicamente, do conceito do dano, os danos são um índice fundamental para se vislumbrar as aplicações viáveis da noção de responsabilização. O Brasil é campeão na prática de danos sociais e ambientais - isso permitiria exigir que cuidasse da sua própria responsabilização? Trata-se de uma responsabilização que deve ser promovida contra o Brasil, por parte dos organismos internacionais? Há mesmo sentido em pensar responsabilização social ou ambiental quando o agente causador é praticamente um ente de imaginação, uma figura abstrata? Qual a recuperação que se promove por meio da responsabilidade social ou da responsabilidade ambiental?

Questões sobre a responsabilidade civil são inúmeras, mas falta uma consideração direta das suas condições de abordagem universal, científica e consistente. Em lugar disso, como é comum no "debate" jurídico, a tendência é conduzir o pensamento para uma construção argumentativa que possibilite chegar a determinada finalidade pragmática (aquela postura do falacíloquo mencionada anteriormente). É como se o pensamento jurídico devesse se ater a uma apresentação de soluções imediatas para questões práticas de escritórios de advocacia. Ora, nenhum pensamento racional consegue manter a consistência 
se é conduzido ao sabor dos imediatismos. É preciso que o pensamento jurídico seja uma prática constante de avanço intelectual, o que só se conquista se mantivermos sempre presentes as nossas questões fundamentais.

O fato é que não estamos acostumados a fazê-lo no Brasil. Ao contrário, falta ao nosso ambiente jurídico universitário o costume do diálogo constante e do encontro entre as teorias, as disciplinas, os departamentos e, inclusive, as faculdades. Como pode alguém em São Paulo saber o que pensa sobre determinada questão, considerada relevante por outro acadêmico do Maranhão, por exemplo, se dentro dos próprios departamentos da universidade esse diálogo inexiste? Será mesmo possível falar em comunidade jurídica se nem sequer nos comunicamos? Ou se a nossa única comunicação é telepática de um mesmo silêncio?

$\mathrm{O}$ ideal seria freqüentemente fazer um amplo levantamento do que tem sido efetivamente escrito, dito ou pensado em todo o Brasil a respeito da responsabilidade civil. Fazer um levantamento dos nossos questionamentos, nossas imprecisões, nossas dúvidas e nossos enganos. Divulgar ao público nossa necessidade de construir uma teoria geral da responsabilidade civil que fosse autenticamente brasileira, expressando as nossas diferenças e peculiaridades culturais, bem como as causas para a existência de uma multiplicidade cultural de soluções de responsabilização e práticas de precaução ou prevenção. Explorar, em suma, a nossa cidadania, tão ridicularizada quando deveria ser respeitada e tão respeitada quando deveria ser ridicularizada.

Não se sabe se para isso, todavia, seria de valia suficiente a criação de um instituto brasileiro de direito dos danos. A idéia é interessante, mas o essencial é haver, antes, a discussão entre os autores e os acadêmicos em vez de querer movê-la à força por meio dos trabalhos ou cobranças do instituto. É essa discussão, factualmente travada, que se pede e que se almeja aqui, independentemente das oportunidades de criação textual ou doutrinária que se forme a partir dela. Trata-se de propiciar a reflexão da responsabilidade civil em si mesma, bem como de tomar as obras que se defendem ou se publicam sobre a responsabilidade civil e apresentá-las na arena da avaliação crítica, fora, portanto, de uma apreciação religiosa, simplesmente ideológica, ou sem considerandos. É preciso fundar e disseminar as práticas de questionamento doutrinário, e não há melhor lugar para isso do que a própria graduação em Direito. Ao contrário do que costumam pensar os próprios professores, é no curso de graduação que se deve propor aos alunos a leitura crítica dos autores, em especial porque essa leitura tenderá a não mais ser viabilizada quando se houver iniciado a prática profissional. Por falta de tempo, não haverá como recuperar o tempo perdido.

E é interessante notar que muitos acadêmicos de Direito reagem bem à idéia de uma leitura crítica dos autores jurídicos, porque vêem nisso (o que é verdadeiro) uma oportunidade certa de sair da abordagem tecnocrata e dogmática que domina as salas de 
aula. Por que não tentá-lo, independentemente de qual for o resultado? Seria um ótimo exercício de introdução à iniciação científica ou de enriquecimento e questionamento das metodologias de pesquisa.

Principalmente, pensamos que seria o caso de confrontar, até o limite, as diversas teorias sobre a responsabilidade civil. Seria o caso de investigar coletivamente, como em um laboratório, mas, principalmente, como em um grupo de estudos, a validade prática da aplicação de cada teoria na reflexão sobre os danos e no esclarecimento do poder reparatório. Além disso, seria um meio exemplar de explicitar o quão longe a nossa doutrina como um todo ainda está distante do cumprimento da missão - antes longamente descrita - de pensar os fundamentos da responsabilidade civil e, inclusive, de esclarecer o que devemos compreender por reparação.

Reparação deve ser entendida apenas como sinônimo de indenização? Essa é uma questão certamente sem fim, e que justamente por isso não pode ter como resposta única as pretensões da indústria da indenização.

Igualmente, cumpriria a autores, professores e alunos fazer justiça aos próprios acadêmicos de Direito e usar corretamente os mecanismos de citação e de indicação de referências em termos de autoria intelectual dos textos. Há bibliotecas inteiras de obras escritas (ou plagiadas) pelos acadêmicos, e cabe investigar e anunciar quais são as grandes e verdadeiras inovações, quais são os autênticos momentos de conquista de respostas válidas, quais as novas questões que foram verdadeiramente vislumbradas pelos leitores iniciantes em direito dos danos. Por não estarem ainda viciados com as demandas e inconsistências da vida profissional, os acadêmicos têm o poder, muito maior que o de seus próprios professores, de descobrir o novo - e, muitas vezes, os expressam em seus estudos pessoais e suas monografias de fim de curso, as quais, todavia, são relegadas, na maior parte dos casos, à gaveta. ${ }^{2}$

É preciso dar o devido lugar às conquistas e descobertas relevantes dos alunos, pois essa é a melhor maneira de lhes mostrar como são valiosos e imprescindíveis para a renovação do próprio pensamento jurídico.

Deve-se, pois, sempre aliar inovação pedagógica e inserção na política universitária. Propor aos alunos uma nova maneira de ver a responsabilidade civil envolverá, então, propor que pensem o seu próprio papel como acadêmicos de Direito. Nem poderia ser outro o pedido que se faz a acadêmicos que, indiretamente, são convidados a se tornarem melhores cidadãos. Não por acaso, será a universidade - entendida como ideal, e não como instituição, conjunto de edifícios ou de funções -, o ambiente propício ao desenvolvimento de uma nova e complexa noção de responsabilidade: a responsabilidade

\footnotetext{
2 Ver, especialmente: ANDRADE, F. D. A monografia jurídica: livro, artigo ou gaveta? Revista da Faculdade de Direito de São Bernardo do Campo, São Bernardo do Campo, v. 7, p. 54-71, 2001.
} 
universitária, que pode ser pensada como uma construção de instrumentos para a garantia da preservação das idéias criadas em ambiente universitário ou acadêmico. Por um lado, em vez de tornar a universidade um lugar de padronização ou dogmatização das mentes menos inspiradas e, por outro, de desestímulo ou de plágio das mentes mais originais, o que cabe fazer é reconhecer o valor desse bem jurídico único que é a criação intelectual e garantir a sua preservação e os instrumentos de seu devido aproveitamento e divulgação.

Em um ambiente idealizado dessa maneira, um dos maiores danos que se comete é o plágio, principalmente se considerarmos que os textos jurídicos são, por vezes, pensados para durarem pouco tempo, devendo logo ser substituídos por novas edições ou por novos textos, e, ainda, se considerarmos que a prática da escrita jurídica é transmitida aos alunos como uma forma de obtenção de créditos, e não de aprimoramento intelectual.

O ensino da responsabilidade civil deve ser - já na graduação em Direito e, se possível, antes dela - um ambiente privilegiado para o aprimoramento da nossa consciência do que são os direitos individuais e deveres de preservação desses mesmos direitos. Se as visões especializadas dos doutrinadores que há anos se dedicam ao assunto servirão para construir a consistência de todo o sistema do direito dos danos, é na prática diária da graduação em Direito que nós podemos reconstruir tanto o ensino da responsabilidade civil quanto a própria noção de qualidade do ensino universitário.

Uma vez que a reconstrução desse ideal de excelência universitária exige desfazer equívocos que têm se tornado crônicos, é válido ver, na responsabilidade civil, um momento oportuno para a reconstrução da nossa própria maneira de construir o Direito Civil e a cidadania no Brasil.

10. Quais os resultados dessa reflexão para o ensino do Direito como um todo?

Falar a respeito do ensino da responsabilidade civil nos convida a terminar sempre discorrendo sobre o ensino do próprio Direito.

Uma das verdades a respeito da responsabilidade civil é que, a despeito de ter ela origem no Direito Civil - e é por isso que ela é garantia de civilidade, a partir da noção de responsabilidade -, seu potencial para se comunicar com as outras áreas do Direito é provavelmente inigualável. Por isso, pode-se falar, por extensão, em responsabilidade penal, responsabilidade empresarial, responsabilidade ambiental e assim por diante. E da mesma maneira que, para o ensino da responsabilidade civil, pede-se aos professores de Direito Civil a criação de estratégias que fortaleçam a criação acadêmica conjunta, devese pedir também aos professores das demais áreas exatamente a mesma atitude quando ingressarem nessa ponte com a responsabilidade civil. 
É preciso que a responsabilização não seja vista como uma mina de ouro acessível a todas as áreas do Direito, mas, sim, como o elemento de uma atitude - a interdisciplinaridade - que é fundamental para a transformação de todo ensino jurídico em um instrumento de aprimoramento da cidadania. A perspectiva reflexiva da responsabilidade civil mostra que o seu ensino pode criar verdadeiramente experiências de redescoberta da noção de cidadania, retirando o direito das suas tendências tecnocráticas e devolvendo-lhe sua capacidade criativa que em algum lugar se perdeu.

Não se trata de fundar um novo "direito achado na rua", em que vale tudo. Longe disso!

Trata-se de permitir, todavia, que o ensino do Direito alcance a vida do cidadão, e que o estudante de Direito se compreenda também como cidadão, no sentido interdisciplinar e humanístico do termo. Será que o ensino jurídico é ambiente intelectual propício para isso? Estamos certos que sim, desde que primeiro superemos os padrões de dogmatização do pensamento.

O ensino democrático do Direito, por fim, é uma descoberta conjunta - tanto que é democrático. Não se pode prever como ele será antes de ser feito, mas é impossível que ele não renda bons frutos onde for iniciado ou experimentado.

Provavelmente - e que assim seja - não chegaremos a um novo modelo único de estudo da responsabilidade civil e do direito como um todo, mas, sim, a muitos outros novos modelos que correspondam às visões pedagógicas localizadas e particularizadas possíveis de se manifestar no interior deste nosso grandioso País. O pensamento jurídico brasileiro, assim como qualquer forma cultural de pensamento ou técnica, tem um potencial e uma criatividade impressionantes que, todavia, tendem a ser relegadas ao engavetamento e ao esquecimento. É preciso confrontar esse mau costume. É necessário convidar os acadêmicos de Direito a confrontarem a visão jurídica sobre todos os assuntos, a qual está acondicionada em fórmulas prontas encontradas nos manuais.

É preciso, também aqui, virar a mesa.

São Paulo, setembro de 2008.

Referências

ANDRADE, F. D. A monografia jurídica: livro, artigo ou gaveta? Revista da Faculdade de Direito de São Bernardo do Campo, São Bernardo do Campo, v. 7, p. 54-71, 2001

HIRONAKA, Giselda Maria Fernandes Novaes. Responsabilidade pressuposta. Belo Horizonte: Del Rey, 2005.

ROUVILLOIS, Frédéric. Le droit. Paris: GF Flammarion, 1999. (Collection Corpus). 
STOYANOVITC, K. La responsabilité historique. Archives de Philosophie du Droit, Paris, n. 22, p. 143-160, 1977.

TERRÉ, F. Propos sur la responsabilité civile. Archives de Philosophie duDdroit, n. 22, Paris: Sirey, p. 37-44, 1977.

VINEY, G. Responsabilité. Archives de Philosophie du Droit, Paris: Sirey, n. 35, p. 275-292, 1990.

VINEY, G. Traité de droit civil: introduction à la responsabilité. 2. ed. Paris: Librairie Générale de Droit et de Jurisprudence, 1995.

VINEY, G.; JOURDAIN, P. Traité de droit civil: les conditions de la responsabilité. 2. ed. Paris: Librairie Générale de Droit et de Jurisprudence, 1998. 